\title{
EVOLUTIONARY ENFORCEMENT AT THE SECURITIES AND EXCHANGE COMMISSION
}

\author{
Jayne W. Barnard ${ }^{*}$
}

\begin{abstract}
Hundreds of critics in the past eighteen months have heaped abuse on the SEC Enforcement Division. How could the Division have missed so much misbehavior on Wall Street? How could the Division's young lawyers have been charmed by Bernie Madoff and thwarted from discovering his terrible crimes?

Most critics seem to agree that the Division's most urgent needs include developing substantially more financial sophistication among Division lawyers and investigators; better communications within the Commission and with other federal agencies; and a meaningful system for handling tips and processing information.

The SEC's response to its critics has been remarkable. The Commission has enlisted an energetic cadre of former federal prosecutors to lead the Division. They have redeployed comfortable, desk-bound middle managers back into the field to investigate market misconduct. Reversing the Commission's tradition of micromanagement, they have given senior lawyers new authority to issue subpoenas and initiate settlements. A major reorganization plan is already underway.

The SEC, in short, is in the midst of "the most significant revamp of the division in the last 30 years." This Article begins with the optimistic hope that the current reorganization is successful in meeting the most urgent needs of the Division. It then sketches out six suggestions for further improving the Enforcement Division: a bounty program to compensate informants who come forward with useful information; a victim services unit; a proposal to develop behavioral expertise within the Division; a surveillance and monitoring program for defendants demonstrating a recidivist profile; a sanction policy for individuals that is proportionate, progressive, remedial, and real; and regular publication of meaningful data regarding losses from fraud in the securities markets.
\end{abstract}

Many people in the past eighteen months have expressed their fury at the failures of the Securities and Exchange Commission (SEC). Some of the most impassioned criticisms have been directed at the SEC's Enforcement Division. Critics have lambasted Enforcement for failure to employ modern data-mining techniques in order to sniff out fraudulent online investment schemes; failure to respond to credible evidence of fraud because Enforcement lawyers and

\footnotetext{
* James Goold Cutler Professor of Law and Herbert V. Kelly, Sr., Professor for Teaching Excellence (2009-10), William \& Mary Law School. Thanks to Josh Booth 3L and Brittany Mohler 2L for their research and cite-checking assistance on this project. Trevor Hall, William \& Mary class of 2009, wrote an excellent seminar paper for me in 2008 that very much informs my "no second chance" rule. Janice Craft, class of 2010, discussed victim advocacy practices with me. Three good friends, all alumni of the SEC Enforcement Division, brainstormed with me (anonymously) about portions of this Article. As always, John Tucker provided incisive editorial comments. Special thanks to Peter Oh for organizing this excellent symposium.
} 
investigators lacked the financial sophistication to understand complex transactions and modern trading techniques; failure to interact and exchange information with other SEC divisions and other federal regulators; failure to deploy adequate resources to deal with complex investigations; and management failures in assignment and prosecution of specific Enforcement cases.

Some critics also think the Division has spent so much time on "little" cases and "little" defendants that it has missed the forest for the trees. ${ }^{1}$ Critics and supporters alike have offered many suggestions for reform of the Enforcement Division. The U.S. Chamber of Commerce has urged the SEC to develop a knowledge management program to facilitate intra-agency exchange of information. ${ }^{2}$ The Government Accountability Office has recommended that the Enforcement Division revisit the "level and mix of resources available to investigative staff in the areas of administrative and paralegal support, specialized services and expertise, and information technology support."”

Recently, the SEC's own Inspector General identified multiple failures in the SEC's handling of allegations against Ponzi schemer Bernie Madoff. In a wide-ranging critique of the Commission's unproductive investigations of Madoff spanning nearly two decades, the Inspector General noted the lack of training for young lawyers with little knowledge of the securities markets, ${ }^{4}$ "inexperienced Enforcement staff," 5 and lack of essential follow-up in conducting investigations. ${ }^{6}$ His recommendations for reform of the Division included such obvious items as more training, better procedures for the handling of tips and complaints, ensuring that enforcement teams have at least one team member with experience and expertise (such as in dealing with Ponzi

1. See generally Joe Nocera, S.E.C. Chased Small Fry While Big Fish, Madoff, Swam Free, N.Y. TIMES, June 27, 2009, at B1.

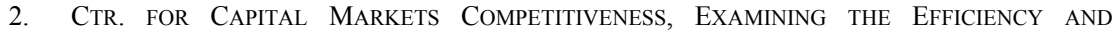
EFFeCtiveness of the SeCurities AND EXCHANGE Commission 23 (Feb. 2009), available at http://www.uschamber.com/assets/ccmc/090211ccmc_sec_speed.pdf(last visited Feb. 16, 2010). Jonathan G. Katz, former Secretary of the SEC, was commissioned by the Chamber of Commerce to conduct this report and make recommendations.

3. GAO, REPORT to CONGRESSIONAL REQUeSTERs, SECURITIES AND EXCHANGe COMMISSION: Greater Attention NeEded to ENHANCE COMMUNiCATION AND Utilization of Resources In the DIVISION OF ENFORCEMENT 50 (March 2009), http://www.gao.gov/new.items/d09358.pdf.

4. U.S. SEC. \& EXCH. COMM'N OFFICE OF INVESTIGATIONS, INVESTIGATION OF FAILURE OF THE SEC to Uncover Bernard Madoff's Ponzi Scheme-Public Version 29 (Aug. 31, 2009), http:// sec.gov/news/studies/2009/oig-509.pdf [hereinafter INVESTIGATION OF FAILURE].

5. $\quad I d$. at 24.

6. Id. at $34,39,41$ and 310 . 
schemes), better supervision, and more consistent attention to staff concerns about internal communications and managerial support. ${ }^{7}$

The SEC's new Chairman, Mary Schapiro, has responded to these and other recommendations by hiring "tough cops" from outside the agency to head the Enforcement Division. ${ }^{8}$ The new Enforcement Division director, Robert Khuzami, has altered the Division's performance metrics to emphasize "quality, timeliness and deterrent impact" rather than simply the number of cases initiated. ${ }^{9}$ He has also decreased the levels of bureaucracy by stripping out a layer of middle management in the Enforcement Division. ${ }^{10}$ Significantly, Khuzami recently reorganized the Division into practice groups to emphasize transaction-specific expertise. ${ }^{11}$ Khuzami has acknowledged the need for both meaningful and visible reforms in the Division. He has also acknowledged a "sense of urgency" in getting the Division back on track. ${ }^{12}$

This Article begins by recognizing the significant shake-up that has already occurred within the Enforcement Division under Khuzami's leadership. ${ }^{13}$ It acknowledges that no reforms are more urgently needed than building up the staff's ability to understand today's sophisticated financial markets; decipher complicated structured investment products; receive, triage, and process information from informants; and have the training and resources necessary to be able to enforce the law in a challenging, competitive, internationalized, and rapidly-changing economic environment.

This Article operates under the assumption (which may turn out to be wildly optimistic) that the most urgent reforms in the Division-building expertise and keeping motivation high —will be implemented successfully. It then sketches out several additional suggestions for further improving the Division's enforcement efforts. These suggestions include: (1) a bounty program to compensate informants who come forward with useful information;

7. U.S. Sec. \& EXch. Comm'N Office of Inspector Gen., Office of Audits, Program ImPRovements NEEDED Within the ENFORCEMENT Division (Sept. 29, 2009), http://www.sec-oig .gov/Reports/AuditsInspections/2009/467.pdf.

8. See infra Part I and accompanying text.

9. Yin Wilczek, Khuzami Cites Move to Specialized Teams, Other Initiatives to Improve SEC Enforcement, 41 SEC. REG. \& L. REP. (BNA) 849 (May 11, 2009).

10. Yin Wilczek, In Mid-Year Reviews, Lawyers Give Enforcement Division High Marks for Revamp, 41 SEC. REG. \& L. REP. (BNA) 1362 (July 20, 2009).

11. John Herzfeld \& Phyllis Diamond, Khuzami Unveils Broad Reorganization of Enforcement Div'n, New Subpoena Powers, 41 SeC. Reg. \& L. ReP. (BNA) 1473 (Aug. 20, 2009).

12. Kara Scannell, “Urgency” Drives SEC Crackdown, WALL ST. J., Aug. 11, 2009, at C1.

13. Yin Wilczek, Specialized Units Should Be in Place By Beginning of New Year, SEC Official Says, 41 SEC. REG. \& L. REP. (BNA) 1777 (Sept. 28, 2009) ("The shake-up is said to be "the most significant revamp of the division in the last 30 years."); see infra Part I. 
(2) a victim services unit within the Enforcement Division; (3) a proposal to add behavioral expertise to the investigational resources of the Division; (4) a surveillance and monitoring program for offenders demonstrating a recidivist profile; (5) a sanction policy for individual defendants that is proportionate, progressive, remedial, and real; and (6) regular publication of meaningful data regarding losses from fraud in the securities markets. ${ }^{14}$ Each of these proposals would strengthen the Enforcement Division and assist in its mission of protecting investors.

\section{A BIRD’s EYE VIEW OF RECENT DEVELOPMENTS IN THE ENFORCEMENT DIVISION}

The Enforcement Division has undergone a radical transformation since Mary Schapiro was sworn in as SEC Chairman in January, 2009. Not only did Schapiro quickly cashier and replace long-time Division Chief Linda Chatman Thomsen. ${ }^{15}$ Both the House Financial Services Committee and the Senate Banking Committee convened public hearings to explore the myriad failings of the Division (and other units of the Commission) throughout the preceding decade. ${ }^{16}$ Ironically, there were no Congressional hearings when the previous SEC Chairman set up a series of procedures that hobbled the Enforcement Division. $^{17}$

The Commission very quickly appointed three key players to lead the Enforcement Division: (1) Robert Khuzami, a former prosecutor in the U.S. Attorney's office for the Southern District of New York and, at the time of his appointment, General Counsel for the Americas at Deutsche Bank AG: ${ }^{18}$ (2) George Canellos, former Chief of the Major Crimes Unit in the U.S. Attorney's office for the Southern District of New York and, at the time of his appointment, a partner in the New York firm of Milbank, Tweed, Hadley \&

14. See infra Parts II-VII, respectively.

15. Press Release, U.S. Sec. and Exch. Comm'n, Enforcement Dir. Linda Chatman Thomsen to Leave SEC (Feb. 9, 2009), http://www.sec.gov/news/press/2009/2009-22.htm.

16. See generally Madoff Investment Securities Fraud: Regulatory and Oversight Concerns and the Need for Reform: Hearing Before S. Comm. on Banking, Housing and Urban Affairs, 111 th Cong. (Jan. 27, 2009); see generally Assessing the Madoff Ponzi Scheme and Regulatory Failures: Hearing Before the $H$. Financial Services Comm., Subcomm. on Capital Markets, Insurance, and Government-Sponsored Enterprises Hearing, 111th Cong. (Feb. 4, 2009).

17. See Otis Bilodeau, SEC's Cox Tightens Reins on Enforcement Division, BloOMBERG.COM, Apr. 13, 2007, http://www.bloomberg.com/apps/news?pid=20601087\&sid=aodWCvu220YE\&refer=home.

18. Khuzami Will Lead SEC Enforcement Division, WALL ST. J., Feb. 20, 2009, at C3; Press Release, U.S. Securities and Exchange Commission, Robert Khuzami Named SEC Director of Enforcement (Feb. 19, 2009), http://www.sec.gov/news/press/2009/2009-31.htm. 
McCloy; ${ }^{19}$ and (3) Lorin Reisner, also a former prosecutor and, at the time of his appointment, a partner in Debevoise \& Plimpton LLC ${ }^{20}$ They walked into a Division that was under-resourced, demoralized, and insecure. ${ }^{21}$

Khuzami immediately began to talk about some of the Division's most needed reforms: More trial lawyers, more paralegals, and better information technology. ${ }^{22}$ Chairman Schapiro floated the idea of a "fraud college" to train the staff to better spot market abuses. ${ }^{23}$ Inevitably, the Enforcement staff felt both pride and fear as the Division unveiled its management changes. ${ }^{24}$

In August of 2009, Khuzami reflected on the early days of his leadership during a major policy speech to the Association of the Bar of the City of New York. ${ }^{25} \mathrm{He}$ cited increased activity in the Division (based on numbers of investigations opened and cases filed); the "flattening of management" by redeploying branch chiefs to handle less paper and conduct more on-theground investigations; delegation of power to senior lawyers in the regional branches to handle "routine case decisions"; delegation to the same senior lawyers of the power to initiate formal investigations with accompanying subpoena power; and streamlining the cumbersome "Action Memo" process (seeking authorization from the full Commission). ${ }^{26}$

On August 31, 2009, the SEC's Inspector General issued an unprecedented report examining dozens of contacts between the Commission

19. Kara Scannell, Canellos to Run SEC in New York, WALL ST. J., June 3, 2009, at C3; Press Release, U.S. Sec. and Exch. Comm'n, George S. Canellos Named as Regional Director of SEC Regional Office (June 2, 2009), http://www.sec.gov/news/press/2009/2009-125.htm.

20. Kara Scannell, SEC Names Deputy Enforcement Director, WALL ST. J., July 2, 2009, available at http://online.wsj.com/article_email/SB124656228827387801-IMyQjAxMDI5NDE2MjUxNjIyWj.html; Press Release, U.S. Sec. and Exch. Comm'n, Lorin L. Reisner to Join SEC Enforcement Division (July 2, 2009), http://www.sec.gov/news/press/2009/2009-150.htm.

21. See generally Donald C. Langevoort, The SEC and the Madoff Scandal: Three Narratives in Search of a Story (Georgetown Univ. Law Ctr., Working Paper No. 1475433, 2009), available at http://scholarship.law.georgetown.edu/cgi/viewcontent.cgi?article=1118\&context=fwps_papers (noting the inevitable limitations imposed on SEC enforcement staff and the beleaguered mindset that results).

22. Gibson, Dunn \& Crutcher, LLP, The SEC in Transition: A Mid-Year Review of SEC Enforcement in 2009, (July 9, 2009), http://www.gibsondunn.com/Publications/Pages/SECinTransition-MidYearReviewSECEnforcement.aspx.

23. Joshua Gallu \& Dawn Kopecki, SEC May Send Staff to "Fraud College" to Detect Future Madoffs, BLOOMBERG.COM, Sept. 3, 2009, http://www.bloomberg.com/apps/news?pid=20601087\&sid= aO6As7nsq.wo.

24. Zachary A. Goldfarb, SEC Upsets Some as It Tries to Sharpen Teeth: Several Moves Draw InHouse Criticism, WASH. POST, July 15, 2009, at A13.

25. Robert Khuzami, Dir., U.S. Sec. \& Exch. Comm'n, Remarks Before the New York City Bar: My First 100 Days as Director of Enforcement (Aug. 5, 2009), http://www.sec.gov/news/speech/2009/ spch080509rk.htm [hereinafter Khuzami, My First Hundred Days].

26. $I d$. 
staff and Bernie Madoff over a sixteen-year period. ${ }^{27}$ His conclusions were blistering, both about the failures of the Enforcement Division and those of the SEC's Office of Compliance Investigations and Examinations (OCIE). The Senate Banking Committee quickly reconvened to heap more abuse onto the Division and its lawyers. ${ }^{28} \mathrm{~A}$ few weeks later, the Commission itself released a new Strategic Plan, setting ambitious goals - such as a 90\% "success" rate and no more than $8 \%$ employee turnover-for the Enforcement Division. ${ }^{29}$

The most constructive development during this tumultuous year has undoubtedly been the decision to re-engineer the Division to promote communication, continuity, and expertise. As early as April, 2009, the Division's new leaders signaled that they would establish teams of specialists to focus on particular types of fraud schemes. ${ }^{30}$ In August, 2009, they unveiled the new structure, announcing the creation of five specialized units: Asset Management (focusing on investment advisers, investment companies, hedge funds, and private equity funds); Market Abuse (focusing on large-scale market abuses and complex manipulation schemes by institutional traders, market professionals, and others); Structured and New Products (focusing on complex derivatives and financial products, including credit default swaps, collateralized debt obligations, and securitized products); Foreign Corrupt Practices Act; and Municipal Securities and Public Pensions. ${ }^{31}$

In addition, the SEC will create an Office of Market Intelligence that will be responsible for "the collection, analysis, risk-weighing, triage, referral and monitoring of the hundreds of thousands of tips, complaints and referrals that the Agency receives each year." 32 And the Enforcement Division will appoint a chief operating officer who will "manage information technology, oversee project management and build efficient workflow processes.",33

In announcing this reorganization, the Division's new Director, Robert Khuzami, also emphasized a number of other themes: focusing on cases

27. See InVESTIGATION OF FAILURE, supra note 4.

28. See Madoff Investment Securities Fraud: Regulatory and Oversight Concerns and the Need for Reform: Hearing Before the S. Comm. on Banking, Housing, and Urban Affairs, 111 th Cong. (Sept. 10, 2009) (Opening Statement of Senator Christopher J. Dodd, Chairman), available at http://banking .senate.gov/public/index.cfm?FuseAction=Newsroom.PressReleases\&ContentRecord_id=a5f88d12-b3400844-534a-166a8de98523.

29. Press Release, U.S. Sec. \& Exch. Comm'n, SEC Publishes 2010-2015 Draft Strategic Plan for Public Comment (Oct. 8, 2009), http://www.sec.gov/news/press/2009/2009-216.htm. at $\mathrm{C} 1$.

30. Kara Scannell, SEC Plans Crime Fight With Teams of Specialists, WALL ST. J., Apr. 29, 2009,

31. Herzfeld \& Diamond, supra note 11.

32. Khuzami, My First Hundred Days, supra note 25.

33. Id. 
involving the "greatest and most immediate harm" and on cases that send "an outsized message of deterrence"; working to "better determine on an informed basis whether to continue an investigation"; and "building strong cases so that defendants [will] settle quickly." ${ }^{34}$ Khuzami's ultimate goal, he said, was for the Division to be more "nimble." We need "to move our cases more quickly and to free up time and resources to take on new matters with greater urgency and impact." 35

Khuzami deserves cautious praise for these initiatives. Re-inventing a complex, lawyer-heavy workplace is a huge undertaking, and it may fail. Assume, however, that these initiatives are successful. What else might the Enforcement Division do?

\section{THE SEC SHOULD IMPLEMENT A BOUNTY PROGRAM FOR INFORMANTS WHO COME FORWARD WITH USEFUL INFORMATION}

People in the financial industry are singularly motivated by wealth. Yet, in case after case where observant participants must have known about financial wrongdoing, nobody came forward. Nobody blew the whistle. ${ }^{36}$ Why? Because there was little reason to do so. Whistleblowing is generally thankless and painful. ${ }^{37}$ It is time to create an SEC bounty program to reward people who come forward with useful information about fraud.

The SEC already has statutory authority to pay bounties to informants who provide information about insider trading. ${ }^{38}$ This bounty authority has

34. Id.

35. Id.

36. See, e.g., Malcolm SALter, InNOVAtion Corrupted: The ORigins AND Legacy OF ENRON'S COLLAPSE 125 (2008) ("Many employees were apparently well aware of Enron's dissimulations-some even joked about their pervasiveness. According to vice president Sherron Watkins, the giant green overlay on the lush tropical scene on the cover of Enron's 1997 annual report quickly became known internally as 'the fig leaf' obscuring the company's financial status and performance.").

37. See Geoffrey Christopher Rapp, Beyond Protection: Invigorating Incentives for Sarbanes-Oxley Corporate and Securities Fraud Whistleblowers, 87 B.U. L. REV. 91, 95 (2007) (enumerating the disincentives typically faced by whistleblowers, including the possibility of destroying the company for which they work, fear of blacklisting from future employers, fear of social ostracism, and psychological burdens).

38. 15 U.S.C. $\S 78 \mathrm{u}(1)(\mathrm{e})(2006)$. 
rarely been used..$^{39}$ This fact may not be surprising since there is a history of antipathy to paying such bounties within the Enforcement Division. ${ }^{40}$

The SEC's own Inspector General, however, has recently urged the Commission to seek Congressional authority to create a new bounty program that would pay for information about any securities law violation. Such a program, he says, would provide the necessary incentives for people with knowledge (or even well-founded suspicion) to bring forward information about possible illegal activity. ${ }^{41}$ SEC Chairman Mary Schapiro has also suggested she favors a broader bounty program. "Right now, the main reward for being a whistleblower is the good feeling you get of having done something important, because we don't have the authority to pay," she told the House Appropriations Committee. ${ }^{42}$ She favors the notion of a broad-spectrum bounty program, because "[w]histleblowers tend to do a lot of the work for you, hand you something that's pretty fully baked." ${ }^{43}$

Professor Pamela Bucy has been even more specific about the value of informants and the need for financial incentives to encourage them to come forward:

Public regulators, law enforcement, administrative agencies cannot effectively detect, prove, or deter complex economic wrongdoing without inside information. It is just too hard to piece together what is wrong.

$$
* * *
$$

I practiced as an Assistant United States Attorney from 1980 to $1987 . \ldots$ I worked with agents to investigate and then prove white collar crimes. Most of our investigations of white collar cases took a couple of years. They were tedious,

39. One researcher reports that the SEC has paid only four bounties since 1989. He describes the SEC's program as "all but ignored and unused for its 20+ year history." Bruce Carton, New Opportunities for Bounty Hunters, COMPLIANCE WK., July 3, 2009, http://www.complianceweek.com/blog/carton/2009/ 07/03/new-opportunities-for-sec-bounty-hunters/.

40. When the possibility of SEC bounty authority first surfaced in Congress in 1988, the prospect caused considerable alarm within the Commission's enforcement staff: According to Lawrence Iason, Regional Administrator of the SEC's New York office, the bounty provision will create so much havoc, the agency should consider never using it: "The Commission should consider taking the position it will never enter into these arrangements." The New York chief said the SEC already receives tips from informants, some of them valuable and many of them worthless, but with the new legislation, people will be coming out of the woodwork with allegations. "Staff will be overburdened trying to sort out which leads to pursue, determining in successful cases who is entitled to the money, and defending its actions in court," he said. Barbara Franklin, Mutiny Over the Bounty? SEC Lukewarm on New Investigative Tool From Congress, N.Y. L.J., Nov. 17, 1988, at 5.

41. Joanna Chung, SEC Urged to Reward Whistleblowers, FIN. TIMES, July 1, 2009, available at http://www.ft.com/cms/s/0/ffeb6ef4-6665-11de-a034-00144feabdc0.html?nclick_check=1.

42. David R. Sands, Feds Might Offer Bounties for Market Miscreants, WASH. TIMES, Mar. 12, 2009, at $\mathrm{A} 01$.

43. Id. 
laborious, slow step-by-step investigations. We would get some information, maybe from a victim, maybe from a competitor, that something was wrong. But we certainly didn't have enough information to figure it out.

We would seek grand jury subpoenas for some records. From those records we would get an idea of what bank accounts might be involved, then we subpoenaed those bank accounts, look on the back of the checks, see where those checks were going.

The grand jury would issue more subpoenas.

And then when we got to the point of actually talking to some witnesses, we never were sure if we were starting with the right ones. If we started interviews with someone who had more liability than we thought, we had records destroyed or altered. Those witnesses would walk out of the interview and boom, the records were gone, or altered.

The point is, without an insider to guide an investigation, detecting, investigating and proving complex wrongdoing is very difficult. ${ }^{44}$

Many, many federal agencies have had success with bounty programs. The IRS, for example, has collected hundreds of millions of dollars in unpaid taxes based on information received from informants under its bounty program. ${ }^{45}$ Other federal agencies, too, provide models of effective bounty programs. The government pays bounties for information about unlawful behavior in government contracting. ${ }^{46}$ It also pays bounties for information about violations of the federal banking laws, ${ }^{47}$ the Clean Air Act, ${ }^{48}$ CERCLA,${ }^{49}$

44. Interview with Pamela Bucy, Professor of Law, Univ. of Ala. Sch. of Law, Tuscaloosa, Ala., in Corp. Crime Rep. (May 20, 2002); see also Pamela Bucy, Private Justice, 76 S. CAL. L. REV. 1, 55 (2002) ("Economic wrongdoing is difficult to detect and prove. Often, it is hidden within a large organization, buried in paper trails and electronic messages, concealed by false documentation, involves complex and intricate transactions, and has many participants, none of whom may know the full extent of the conduct or even, for some, that there are any improprieties. Reconstruction of the illegality requires sophisticated investigators and attorneys with significant investigative resources and legal skill.”).

45. See IRS WhistLeblower ANNUAL REPORT 6 (2008), http://www.irs.gov/pub/whistleblower/ whistleblower_annual_report.pdf

46. Major Fraud Act, 18 U.S.C. $§ 1031$ (a) (2006).

47. See supra note 40 and accompanying text.

48. 42 U.S.C. $\S 7413$ (f) (2006) (indicating payment of up to $\$ 10,000$ for information leading to a conviction or imposition of a civil penalty).

49. 42 U.S.C. $\$ 9609$ (d) (2006) (indicating payment of up to $\$ 10,000$ for information leading to a conviction). 
the customs laws, ${ }^{50}$ the drug laws,${ }^{51}$ and the U.S. Postal Service rules. ${ }^{52}$ There are, in fact, dozens of bounty provisions scattered throughout the U.S. Code. ${ }^{53}$

There are some drawbacks, of course, to the use of bounty programs. The biggest objection to adoption of an SEC bounty program, as was the case in $1988,{ }^{54}$ will be that the Enforcement Division already receives more tips than it can reasonably handle. The single greatest failure in the SEC's involvement with Bernie Madoff, for example, was the Division's failure to understand and pursue the information brought to it (repeatedly) by Harry Markopolos. (Ironically, Markopolos was driven, in part, by a mistaken belief that he would be entitled to a bounty for the information he shared with Enforcement staff lawyers. $)^{55}$ If the Division does not have the resources-or the analytical capacity-to handle existing tips about securities fraud, then generating more tips can only make matters worse. Therefore, any meaningful proposal for a bounty program must be preceded by the creation of a tip-handling system that is capable of recognizing the kinds of information that are worthy of further pursuit. We can only hope that the new Office of Market Intelligence can meet that threshold requirement.

Even assuming a workable tip-handling apparatus is in place, however, bounty programs can still create problems. Bounty programs may be inefficient, giving rise to specious tips, for example, or encouraging people to "save up" information rather than taking steps to correct the misconduct of which they are aware. Bounty programs may also discourage law enforcement officials from aggressively pursuing their own investigations-it is always

50. 19 U.S.C. $\S 1619$ (2006) (authorizing payments of up to $25 \%$ of the fine or duties collected or $25 \%$ of the value of the confiscated property to any person who provides information that leads to collection of unpaid customs duties or any fine, penalty, or forfeiture of property).

51. D.E.A. AgENTS MANUAL $\S 6612.44$ A.2 (Mar. 24, 1999) (permitting payments for information or assistance leading to a criminal or civil forfeiture of illegal drugs, based on the value of the forfeited items).

52. United States Postal Service, Poster 296 - Notice of Reward (July 2006), http://www.usps.com/ $\mathrm{cpim} / \mathrm{ftp} /$ posters/pos296/welcome.htm (offering rewards up to $\$ 100,000$ for information about violations of the postal regulations).

53. Perhaps the best-known federal bounty program is the False Claims Act, which is regularly cited for its multi-million dollar bounties. See, e.g., Gardiner Harris, Pfizer to Pay \$2.3 Billion to Settle Inquiry Over Marketing, N.Y. TimES, Sept. 3, 2009, at B4 (noting that a salesman who became a whistleblower under the False Claims Act received more than $\$ 50$ million for his role in the case and that a total of $\$ 102$ million in bounties was paid to informants).

54. See supra note 40 and accompanying text.

55. See Andrew Kirtzman, Betrayal: The Life and Lies of Bernie Madoff 85-86 (2009) (noting Markopolos' belief that his information might "make him a millionaire"). In his first meeting with the SEC, he said, "[i]f there is a reward for uncovering fraud, I certainly deserve to be compensated[.]" Id. at 101 . 
easier to wait for an informant to come forward with a package of evidence than to go through the gritty kind of investigation, document review, and transactional reconstruction required to build a securities fraud case. Bounties may also increase demands on regulatory staff, who not only have to sift through informants' tips, but also may have to determine just how much a piece of information is worth (this may be particularly difficult when confronted with the claims of multiple informants). It is possible, indeed likely, that the Enforcement Division would need to create a special task force or unit simply to deal with the expectations of informants. The staff would not only need to sort out the meritorious from the unmeritorious tips, but it might also need to determine the relationship(s) between the informant(s) and the scheme $(\mathrm{s}) .^{56}$

Some critics object to bounty payments because they monetize virtue. And, inasmuch as they discourage voluntary whistleblowing, bounties may also undermine the public's respect for the law. In the debates leading up to the enactment of the bounty provision of the Major Fraud Act, for example, one senator seriously condemned the program as a form of "bribe." "57

Finally, some critics have cautioned that "encouraging citizens to be informers would create an insidious climate of betrayal and mistrust throughout society." ${ }^{, 8}$ As one commentator has put it, when we rely on bounty programs we put ourselves at risk of becoming a "nation of snitches." ${ }^{, 59}$ This seems to me to be a particularly unpersuasive argument. Is it better that people ignore ongoing frauds than that, as a society, we encourage those people to speak up and shut the frauds down? And just how much damage is done to the social fabric when we reward whistleblowers for thwarting economic crimes? I would argue, "not much." We live, after all, in a Panopticon culture. Our friends and coworkers may already be watching every move we make. ${ }^{60}$

And what about the many advantages of bounty programs? As Professor Bucy suggests, bounty programs reduce the cost of law enforcement investigations. They are not only instrumental in bringing forth hidden information — sometimes deeply camouflaged information — at a comparatively

56. See infra note 69 and accompanying text.

57. 135 CONG. ReC. S3314, S3319 (daily ed. Apr. 5, 1998) (statement of Sen. Dale Bumpers).

58. IRWIN ROSS, SHADY BUSINESS 139 (1992).

59. Elletta Sangrey Callahan \& Terry Morehead Dworkin, Do Good and Get Rich: Financial Incentives for Whistleblowing and the False Claims Act, 37 VILL. L. REV. 273, 318 (1992).

60. See Hal Niedzviecki, The Peep Diaries: How We're Learning to Love Watching OURSELVES AND OUR NEIGHBORS (2009). 
low cost. They also cost nothing if the information received is not productive. This is win-win law enforcement.

There are other advantages to informant bounty programs: they enhance the likelihood of detection of wrongdoing and, thus, serve to deter some frauds. Unlike substantive regulation, bounty programs act as a deterrent to fraud without interfering in the legitimate process of capital accumulation; when properly designed, they encourage informants to gather information, analyze what they know, seek out additional documentation, and organize the information in a useful and comprehensible form; they provide an outlet for employees who have been ordered to participate in wrongdoing and have lost or fear for their jobs for refusal to go along. ${ }^{61}$ Bounties generate access to information that otherwise might never come to the attention of the law enforcement agency, especially in circumstances where victims of fraud might not yet know they have been defrauded. In addition, by focusing law enforcement agencies on "true" problems rather than imagined or possible problems, they reduce the cost not only for the enforcing agency but also for defendants who must respond to inquiries and organize a defense.

The existing SEC program for information about insider trading provides for an award of up to $10 \%$ of the proceeds to an informant whose information leads to the imposition of a civil penalty. ${ }^{62}$ This award is discretionary with the SEC and is not subject to judicial review. ${ }^{63}$ It is unavailable to law enforcement officials who discover evidence of fraud in the course of their duties. ${ }^{64}$ The Commission's Inspector General has indicated that he would like to use the existing SEC program as a model, with a couple of interesting tweaks. ${ }^{65}$

61. The Sarbanes-Oxley Act whistleblower provisions are also aimed at this population, but have proven an inadequate incentive to induce whistleblowers to come forward. See Rapp, supra note 37, at 116.

62. 15 U.S.C. $\S 78 \mathrm{u}-1$ (e) (2006).

63. 15 U.S.C. $\S 78 \mathrm{u}-1(\mathrm{e})$.

64. 15 U.S.C. $\S 78 \mathrm{u}-1(\mathrm{e})$.

65. See Letter from H. David Kotz, SEC Inspector Gen., to Congressman Paul E. Kanjorski (June 30, 2009), http://kanjorski.house.gov/index.php?option $=$ com_content\&task=view\&id=1571\&Itemid=1.: 
Another model for a bounty program is that created under the Financial Institutions Reform, Recovery and Enforcement Act of 1989 (FIRREA). ${ }^{66}$ This statute, passed in the wake of the savings and loan crisis, contains a multilayered program for the payment of bounties to informants. It is, among other things, markedly more generous than the SEC's current program. First, informants who provide original information about banking law violations that lead to recovery of a criminal fine, restitution, or civil penalty may be entitled to recover up to $25 \%$ of the amount recovered, or $\$ 100,000$, whichever is less. ${ }^{67}$ As with the current SEC program, bounties are not available under this provision to employees of the government who come into possession of the information in the course of their regular duties ${ }^{68}$ Importantly, they are also unavailable to individuals who knowingly participated in the wrongdoing. ${ }^{69}$

Second, informants who come forward with information about bank fraud that is critical to a criminal conviction may be entitled to receive a reward. ${ }^{70}$ In addition, if the conviction results in a recovery of funds, the informant may also share in the recovery as follows: $20-30 \%$ of the first $\$ 1$ million; $10-20 \%$ of the next $\$ 4$ million; and 5-10 percent of the next $\$ 5$ million. ${ }^{71}$ Third, informants who provide information that leads to the recovery of a defendant's assets have a right to share in the recovery based on the same formula used for those who provide information on the merits. ${ }^{72}$

There are other models, too, that might form the basis for a comprehensive SEC bounty program. ${ }^{73}$ What is most important, however, is not the details of

We would recommend that the Exchange Act be amended to authorize the SEC to award a bounty for information leading to the recovery of a civil penalty from any violator of the federal securities laws, not simply insider trading violations. We would also suggest that the Exchange Act be amended to provide specific criteria for awarding bounties, including a provision that where a whistleblower relies upon public information, such reliance does not constitute an absolute bar to recovering a bounty. The statute should also require that the whistleblower be provided with status reports at certain milestones during the investigation or examination that Id.

was based on the tip.

66. Financial Institutions Reform, Recovery, and Enforcement Act of 1989, Pub. L. No. 101-73, 103 Stat. 183 (codified as amended in scattered sections of 12 U.S.C., 18 U.S.C., and 31 U.S.C.).

67. 12 U.S.C. $\S 1831 \mathrm{k}(\mathrm{b})(2006)$.

68. 12 U.S.C. $\S 1831 \mathrm{k}(\mathrm{c})(2006)$.

69. 12 U.S.C. $\S 1831 \mathrm{k}(\mathrm{c})$.

70. 12 U.S.C. $\S 4205$ (2006).

71. 12 U.S.C. $\S 4205$.

72. 12 U.S.C. § 4225(c) (2006).

73. A particularly thoughtful proposal for a bounty program appears in Marsha J. Ferziger \& Daniel G. Currell, Snitching for Dollars: The Economics and Public Policy of Federal Civil Bounty Programs, 1999 U. ILL. L. REV. 1141 (examining several federal programs and proposing a "model" bounty program that would include: (1) clarity about eligibility for a bounty; (2) certainty of payment, rather than discretion 
how the program would run, but rather obtaining the authority to establish such a program and a commitment within the Enforcement Division to provide a reward for useful information.

\section{THE SEC SHOULD ESTABLISH A VICTIM SERVICES UNIT}

The SEC has long taken the position that it is not a collection agency for victims of securities fraud. Still, in recent years (and with the prodding of Congress), the Commission has vastly improved its record of distributing the proceeds of disgorgement recoveries to victims. ${ }^{74}$ In this respect, the Commission is already providing a critical service for many victims, but it could and should do much more.

Let us begin with the proposition that victims of fraud can suffer terribly from their victimization. They not only lose money, they can also lose selfrespect, their status in the community, their sense of trust, their sense of value to their family, psychological well-being, physical health, hopes for the future, a sense of accomplishment (as evidenced by the wealth they've accumulated over a lifetime), and a sense of competence to manage their own affairs. Many victims of fraud are simply destroyed. ${ }^{75}$

Not insignificantly, many fraud victims redirect their anger and shame from the perpetrator(s) who stole their money to the government agencies that failed to protect them. Bernie Madoff's victims, for example, have excoriated the SEC for its failure to detect Madoff's decades-long scheme. They have held rallies, importuned Congress, written blistering letters to the media, told their stories repeatedly on TV, and testified at Madoff's sentencing. ${ }^{76}$ Wherever they gather, they always include the SEC as well as Madoff as an

on the part of the paying agency; (3) a "low, fixed-percentage bount[y] with no nominal cap," generally in the range of one to three percent of the penalty recovered; and (4) an assurance of anonymity).

74. For example, in Fiscal Year 2008, the Commission "returned more than $\$ 1$ billion to harmed investors through Disgorgement and Fair Fund distributions.” U.S. SEC. AND EXCH. COMM'N, 2008 PERFORMANCE AND ACCOUNTABILITY REPORT 28, available at http:/www.sec.gov/about/secpar/ secpar2008.pdf. The Commission recently established an Office of Collections and Distributions to further pursue the collection of funds for the benefit of investors. Stephen J. Crimmins, The SEC's Blueprint to Reinvigorate Enforcement, 41 SEC. REG. \& L. REP. (BNA) 669, 670 (Apr. 13, 2009).

75. See generally Jayne W. Barnard, Allocution for Victims of Economic Crimes, 77 NOTRE DAME L. REV. 39, 41 (2001) (describing the kinds of harms that typically befall fraud victims).

76. In that proceeding, victims said things like "I am a victim because our government has failed me," "The SEC's incompetence has let this psychopath steal from me," and "[w]e have been devastated by the SEC's failure." Judge Denny Chin finally had to admonish the victims to focus on the task at hand, the sentencing of Madoff, and to stop trying to use the occasion to criticize the government. Jayne W. Barnard, Notes from Madoff's Sentencing (June 29, 2009) (unpublished, on file with author). 
object of their scorn. ${ }^{77}$ R. Allen Stanford's victims, too, sought relief from Congress by arguing, "[federal] agencies, along with Stanford, have robbed [us] of [our] American dream." 78

One way the SEC could help to restore its reputation as the protector of investors would be to create an in-house victim services unit. Employees of this unit would not serve as lawyers for victims, nor as psychotherapists. A victim services unit would, however, professionalize communications with victims, serve as a link between victims and lawyers within the Division, and ensure that victims are, and remain, informed about the progress of the enforcement proceeding.

The SEC currently (and perhaps surprisingly) does not have a designated victim services unit. Occasionally, an Enforcement Division lawyer will work directly with one or more victims to gather facts or prepare their testimony for trial. Sometimes, in big cases, the Enforcement Division creates an informational web page. ${ }^{79}$ More frequently, when a case is settled, a fund administrator is appointed to handle claims and disburse disgorgement proceeds to the victims. Fund administrators may set up a call center or establish a website to help victims with their claims.

The SEC also has an Office of Investor Education and Advocacy that fields inquiries from investors, including those who have been defrauded. But, when the money has been lost, and in the absence of a criminal proceeding, victims of securities fraud are essentially left on their own. ${ }^{80}$ In an odd case of legislative line drawing, victims of frauds whose victimizers are prosecuted criminally receive vastly more victim communication and support than do

77. On the day of Madoff's sentencing, many victims skipped the proceeding in order to attend a rally outside the courthouse where they inveighed against the SEC. They wore T-shirts that read, "SEC FAILED US." Zachery Kouwe, Waiting to See Madoff, an Angry Crowd is Disappointed, N.Y. TIMES, June 30, 2009, at B1. A group of Madoff's victims recently sued the SEC, alleging gross negligence in carrying out its enforcement responsibilities. Diana B. Henriques, Suit Claims S.E.C. Failed to Detect Madoff Scheme, N.Y. TIMES, Oct. 15, 2009, at B11. at B6.

78. Reuters, Agencies Were Told of Stanford Fraud, Investors Say, N.Y. TIMES, Aug. 18, 2009,

79. See, e.g., SEC Case Against R. Allen Stanford (Mar. 12, 2009), http://www.sec.gov/news/ press/2009/2009-26-update.htm.

80. Some fraud victims now engage in self-help via the Internet. Madoff victims, Stanford victims, and other victims' groups have created support sites and chat rooms to communicate with one another. See, e.g., Bernard Madoff Fraud Victims Support Group Website, http://bernardmadoffvictims.org (last visited Nov. 20, 2009). While access to web-based communication provides an alternative to the isolation experienced by previous generations of victims, a centralized repository of victim information would help avoid duplication of effort and forcing victims to reinvent the wheel. 
victims of otherwise identical frauds that are handled through the SEC's civil enforcement system. ${ }^{81}$

What might an SEC victim services unit do? The functions of prosecutorial victim assistance programs can give us some clues: (1) contacting victims to alert them to the unfolding of an enforcement action; (2) explaining the process of civil enforcement and why a particular proceeding will be civil rather than criminal; (3) explaining the possible remedies available in a civil proceeding and soliciting victims' input; (4) assisting victims in assembling and documenting their claims; (5) assisting victims in preparing affidavits, statements, or demonstrative evidence for testimony at trial; (6) communicating with victims about litigation developments, including settlement; (7) preparing victims for court proceedings; (8) accompanying victims to court proceedings; (9) referring victims for psychological support services (not providing direct delivery of services); (10) offering a clearinghouse of information (for example, about tax issues, pending legislation, and, where applicable, submissions to the SIPC); (11) helping to dispel "magical thinking" about the possibility of complete financial recovery; (12) providing follow-up communication with victims after an enforcement proceeding is concluded to make sure they understand their rights; and (13) debriefing victims who have information about the location of assets or possible post-settlement violations of injunctive orders or occupational bars. The keys to victim support are listening to victims' stories, keeping them apprised of developments in the case, and answering their questions about the legal process and their rights.

Why should the SEC add victim services to its already-full plate? Critics could argue that providing victim services only protracts the victimhood experience and often fosters dependency. Others might argue that private lawyers, therapists, family members, and clergy are better situated than government employees to perform the tasks of victim support. Victim support can be labor intensive and requires empathy, patience, and mature judgment. It is therefore expensive and sometimes unwelcome.

81. The Crime Victims Rights Act of 2004 provides to "crime victims" the right to be present at public court proceedings involving the crime and the right to be "reasonably heard at any public proceeding in the district court involving release, plea, sentencing, or any parole proceeding." 18 U.S.C. $\S \S 3771(a)(2)-(4)$ (2006). The statute also directs people in the Department of Justice to "make their best efforts to see that crime victims are notified of, and accorded, the rights described in subsection (a)." $\S 3771(c)(1)$. However, "[n]othing in the CVRA requires the Government to seek approval from crime victims before negotiating or entering into a settlement agreement." In re W.R. Huff Asset Mgmt. Co., 409 F.3d 555, 564 (2d Cir. 2005). As a result of the CVRA, government-funded victim advocates are now very much a part of the federal prosecutorial system. 
One can acknowledge the challenges and costs of victim support but still insist that victims of fraud - even those frauds that, for whatever reason, do not result in criminal prosecution - are victims and $d o$ suffer. They merit respect and support. The time has passed when we can assume that fraud victimization is merely a matter of being too gullible or too greedy; or that our response to victims should be governed by arcane jurisdictional distinctions between the Department of Justice (which is governed by the Crime Victims Rights Act and therefore provides victim support) and the Securities and Exchange Commission (which is not and therefore does not). ${ }^{82}$ As we discovered in the aftermath of the World Trade Center attack on 9/11, victims of crime often care much, much more about having someone listen to their stories than they care about fighting over available dollars. ${ }^{83}$ Within reason, the SEC should have a system in place to listen.

\section{THE ENFORCEMENT Division SHOULD DEVELOP EXPERTISE ABOUT THE BIOGRAPHICAL, BEHAVIORAL, AND PSYCHOLOGICAL CHARACTERISTICS OF INDIVIDUAL SECURITIES LAW VIOLATORS}

Much has been made in recent months of the SEC's inability to follow the trail of complex, derivatives-based trading schemes and other sophisticated sources of fraud on investors. What the Enforcement Division needs, according to critics, are keen mathematical minds trained in finance who can keep up with new products and financial engineering models. ${ }^{84}$ It also needs more people with technological expertise. ${ }^{85}$ Nobody disagrees.

Let me, however, stake out a different claim here. At the same time the SEC expands its financial and technological expertise to detect complex financial schemes, it should also build a knowledge base about the kinds of defendants who engineer these schemes. There is much to be learned through

82. See supra note 81 and accompanying text.

83. See Kenneth R. Feinberg, What is Life Worth? The Unprecedented EfFort to COMPENSATE THE VICTIMS OF 9/11, at 94 (2005) (recounting stories of claimants who refused to fill out the claim forms but wanted Feinberg to hear the stories of their lost loved ones).

84. In response to this critique, the SEC created a new Fellows program to build capacity in the Office of Risk Assessment. Jesse Westbrook, SEC Offering Market Experts Salaries of More Than $\$ 200,000$, BLOOMBERG.COM, Apr. 30, 2009, http://www.bloomberg.com/apps/news?pid=20601087\&sid= aH4eYn28mhrY\&refer=home. The Office of Risk Assessment has since been reorganized and renamed. See SEC Creates New Division, Taps Law Professor as First Director, 41 SeC. Reg. \& L. ReP. (BNA) 1723 (Sept. 21, 2009).

85. See Tom McGinty \& Kara Scannell, SEC Plays Keep-Up in High-Tech Race, Wall ST. J., Aug. 20,2009, at C1 (noting that, "by many accounts, the [SEC] is outmatched by the traders and market venues with technology that is remaking the trading world."). 
systematic study of the biographical backgrounds, behavioral quirks, and psychological profiles of securities law violators. The Enforcement Division should build behavioral expertise alongside the other forms of expertise it is currently seeking. It should create a small unit devoted to the application of forensic psychology to the task of securities law enforcement.

What would the employees of a behavioral unit do? First, they would compile detailed information about the defendants in already-closed securities fraud cases. They might — and should — also conduct forensic assessments of securities law violators sitting in prison. The product of this process would be a rich tapestry of data that might reveal commonalities among these defendants. Reviewing that material in a systematic way might permit some reasonable prediction about which defendants are likely to recidivate or otherwise harm the investing public.$^{86}$ The process, in addition, might provide useful information about the circumstances in which the SEC's civil sanctions - cease-and-desist orders, obey-the-law injunctions, penny stock bars, and officer-and-director bars-are likely to fail.

Second, the behavioral unit would work with investigators and lawyers in current cases, bringing psychological expertise to the table. People in the behavioral unit could (1) assist investigators in conducting background checks and behavioral analyses of targets of investigation; (2) help identify which targets of investigation present a recidivism profile; ${ }^{87}$ (3) help identify those defendants who should be referred for criminal prosecution; (4) help identify those defendants who need not be prosecuted criminally but are nevertheless deserving of forward-looking civil sanctions; (5) assist in designing meaningful remedial provisions for injunctions and occupational bars for those defendants deserving of forward-looking civil sanctions; (6) assist in designing a program for monitoring defendants who have settled their cases but present a high risk of continued violations $;{ }^{88}$ and (7) track future encounters with law enforcement agencies of defendants after they have left the SEC system. Employees of the behavioral unit could also consult on organizational behavioral issues when the defendant is a business enterprise. ${ }^{89}$

86. There is, of course, a rich history of such projects. For example, states for nearly a century have maintained and analyzed data on the characteristics of imprisoned offenders, in order to make informed parole decisions. See Bernard E. Harcourt, Against Prediction: Profiling, Predicting, and Policing IN AN Actuarial Age 47-76 (2007) (detailing the history of these projects). Most of these projects have involved violent offenders.

87. See infra Part V.A.

88. See infra Part V.B.

89. See Jayne W. Barnard, Corporate Therapeutics at the Securities and Exchange Commission, 2008 Colum. Bus. L. Rev. 793, 832 [hereinafter Barnard, Corporate Therapeutics] (noting that a 
Most importantly, employees of the behavioral unit could provide a source of institutional memory and expertise about which sanctions are effective in deterring future misconduct and which are merely cosmetic. By gathering information, tracking it over time, and reaching informed conclusions about what works and what does not in a variety of contexts, the behavioral unit would help the SEC become a "learning organization."

\section{A. Gathering Information About Ponzi Schemers}

Let me be more specific about the kinds of information the behavioral unit would gather. First, such a unit might consider the psychological makeup and biographical milestones of audacious Ponzi schemers like Bernie Madoff, R. Allen Stanford, ${ }^{91}$ Tom Petters, ${ }^{92}$ and Arthur Nadel. ${ }^{93}$ It might also look at some of the less notorious (but equally dangerous) schemers like Bruce Friedman, ${ }^{94}$ Clelia Flores, ${ }^{95}$ and Peter Son. ${ }^{96}$

All of these defendants are alleged to have constructed elaborate deceptions, skimmed money off the top to enrich themselves (often wrapping themselves in cocoons of luxury), used some of the funds to enrich their reputation in the community through conspicuous charitable giving, and were able to establish trust and confidence among thousands of customers, clients, and friends. Why and how did they do it? It isn't enough to say they were

sophisticated understanding of group dynamics is required to achieve meaningful organizational change).

90. There are many definitions of "learning organization." Generally, though, a learning organization is one that "facilitates the learning of its members and continuously transforms itself" to more effectively achieve its goals, http://en.wikipedia.org/wiki/Learning_organization (last visited Nov. 11, 2009).

91. See Julie Creswell et al., Fraud Parade: $\$ 8$ Billion Case is Next in Line, N.Y. TimES, Feb. 18, 2009, at A1 (describing the Texas Ponzi schemer who sought a knighthood in Antigua, lived in the spotlight of sports and charity events, and misrepresented the safety and security of high-yield certificates of deposit sold by his eponymous bank).

92. See Paul Tharp, Buffett Wannabe Tied to \$2B Ponzi Scheme, N.Y. Post, Oct. 2, 2008, at 61 (describing the Minneapolis Ponzi schemer who fancied himself a business genius, "hobnobbed with billionaires and movie stars[,]" and defrauded several major hedge funds of hundreds of millions of dollars).

93. See Leslie Wayne, The Mini-Madoffs, N.Y.TIMES, Jan. 28, 2009, at B1 (describing the prominent Florida money manager who faked his suicide to avoid arrest after being charged with a $\$ 300$ million investment fraud).

94. Stuart Pfeifer, Manager Yields Control of Firms, L.A. Times, Mar. 11, 2009, at B2 (detailing charges against a California man accused of diverting \$17 million of investors' money to his personal use twenty-seven years after he had been convicted and sentenced to prison for grand theft).

95. Stuart Pfeifer, Alleged Scam Targeted Latinos, L.A. TIMES, Apr. 14, 2009, at B2 (describing an alleged scheme that netted $\$ 23$ million).

96. Henry K. Lee, 2 Bay Area Men Sued by SEC-Investment Scam Targeted Koreans, S.F. CHRON., June 10, 2009, at $C 4$ (describing an alleged scheme that netted $\$ 80$ million). 
greedy or evil or uncommonly-skilled liars. A forensic review of these offenders' backgrounds and behaviors might tell us much more.

It is obvious, for example, that Bernie Madoff had some kind of obsessive-compulsive disorder. ${ }^{97}$ Did that condition drive his fraud, facilitate its execution, assist him in avoiding detection, or is it irrelevant in detecting and deterring Ponzi schemers? R. Allen Stanford had delusions of grandeur. ${ }^{98}$ Did his over-the-top sense of self cause him to believe that his Ponzi scheme could go on forever? What did he believe? And what behavioral patterns, if any, are common to other Ponzi schemers?

Here are some possibilities. Many Ponzi schemers have a history of problem gambling. ${ }^{99}$ Some of them have a history of betrayal and wrongdoing in fields other than securities sales. ${ }^{100}$ Many of them have long histories of small-time shady dealings. ${ }^{101}$ Some of them are involved in real estate ${ }^{102}$ or the

97. See Erin Arvedlund, Too Good to Be True: The Rise and Fall of Bernie Madoff 61 (2009) (describing Madoff's insistence on paperless desks, furniture placement at precise right angles, window blinds and computer screens all aligned at the same level, perfectly-hung picture frames, and the use of black - not blue -ink); ANDREW KIRTZMAN, BETRAYAL: THE LIFE AND LIES OF BERNIE MADOFF 60, 117-18 (2009) (noting that, at home, Madoff insisted on perfectly-trimmed hedges; he also "was forever straightening rugs, drapes, objects on his tables." At the office, "he'd get down on his hands and knees in the reception area to straighten out the Persian rug leading to the elevator. A staffer once found him vacuuming his floor at 7:30 in the morning.").

98. See Bryan Burroughs, Pirate of the Caribbean, VANITY FAIR, June 3, 2009, at 76 (noting that Stanford lived in a mansion with a moat, gave "millions to hospitals, theaters, and museums," created the Stanford Cup for international cricket matches, and offered a $\$ 20$ million prize for the winner).

99. See, e.g., Tom Gilroy, Ponzi Scheme Operator Who Targeted Family Members Pleads Guilty, 41 SEC. REG. \& L. REP. (BNA) 1625 (Aug. 31, 2009) (noting that defendant who had operated a Ponzi scheme had lost some $\$ 5.2$ million in clandestine poker games held regularly in a suite at a luxury Beverly Hills hotel); Francis X. Donnelly, Billionaire Boys Club: Execs Accused in \$53 Million Ponzi Scheme, THE DETROIT NEWs, July 29, 2009, at A1 (noting that alleged Ponzi schemers used some of their proceeds to pay gambling debts); Martin Zimmerman, Irvine CEO Hit With Fraud Claims, L.A. TIMES, Apr. 28, 2009, at B2 (noting allegations that alleged Ponzi schemer was a "high-stakes gambler" with ties to Taiwanese organized crime); Charlie Gasparino, Accused Swindler Cosmo Owed Thousands to the Mob, CNBC.COM, Jan. 27, 2009, http://www.cnbc.com/id/28878404 (noting that alleged Ponzi schemer had once owed tens of thousands of dollars in gambling debts to the Genovese crime family).

100. See, e.g., Tina Moore, Checks Out After \$350M Vanishes, Fla. Cops Hunt Another Hedge Fund Scoundrel, N.Y. DAILY NEWS, Jan. 18, 2009, at 18 (noting that alleged Ponzi schemer Arthur Nadel had previously been disbarred for misusing escrow funds); SEC v. YES Entertainment LLC, SEC Litigation Release 16786 (Oct. 31, 2000) (noting that Ponzi schemer had been disbarred for misappropriation of client funds); Daniel J. Lehmann, Ex-Talent Agent Faces SEC Suit in Investing Scam, CHI. SUN-TIMES, Jan. 5, 1995, at 18 (noting that alleged Ponzi schemer was a disbarred lawyer).

101. See, e.g., Michael Beebe, Ponzi Suspect Piccoli Had Earlier Run-In, Buffalo News, Feb. 16, 2009, at B1 (noting that man charged with Ponzi scheme targeted at Catholics and Catholic priests [he has since pleaded guilty] had, in the 1970s, been accused of orchestrating a scheme in which he violated the usury laws in the sale of a home to an elderly woman).

102. See, e.g., SEC v. Global Asset Partners LLC, SEC Litigation Release 20220 (Aug. 1, 2009) 
sex trade. ${ }^{103}$ Most of them are over 40, married, and own their own homes. ${ }^{104}$ Very few of them are women. ${ }^{105}$

Do any of these facts (or others) have meaning in identifying, thwarting, or sanctioning Ponzi schemers? Other than through institutional folklore, I'm guessing the SEC does not know.

\section{B. Gathering Information About Defendants Who Engage in Organizational Fraud}

Behavioral assessment would not just apply to Ponzi schemers. A behavioral unit could also assess the high-level corporate leaders who lead their companies into financial ruin. Conrad Black, Phillip Bennett, and Bernie Ebbers come to mind. ${ }^{106}$ What might we learn by studying these defendants? Even from a distance, there seem to be observable patterns of behavior among the corporate leaders who oversee and facilitate major financial reporting frauds. These executives are generally domineering, narcissistic, charismatic, and grandiose. ${ }^{107}$ To reinforce their inflated self-images, they create fictitious transactions, fictitious profits, and ultimately fictitious business empires. This scenario often repeats itself: A CEO with a strong sense of his own superiority sometimes cannot face the financial realities of his business, and thus initiates ever-growing accounting adjustments to hide the failure of his vision. ${ }^{108} \mathrm{He}$ often enlists subordinates who are reluctant to say no, or are eager to be of help.

Thus, the SEC should learn more as well about the chief financial officers who begin with small accounting "fiddles," then escalate their fraud until it

(noting that defendant charged with orchestrating a $\$ 5$ million Ponzi scheme diverted investor funds to a now-bankrupt Texas real estate project).

103. See, e.g., Chad Bray, SEC Charges Brooklyn Money Manager With Fraud, WALL ST. J., Sept. 9 , 2009, at A6 (noting that defendant charged with operating a $\$ 40$ million Ponzi scheme used some of the investors' funds to finance his pornography business).

104. David Weisburd, Elin Waring \& Ellen F. Chayet, White-Collar Crime and Criminal CAREERS 25 tbl.1.1 (2001).

105. Id. In this study, $99.4 \%$ of the securities law violators were white men.

106. Black, Bennett, and Ebbers are respectively serving six-and-a-half, sixteen, and twenty-five years in prison.

107. See generally Jayne W. Barnard, Narcissism, Over-Optimism, Fear, Anger, and Depression: The Interior Lives of Corporate Leaders, 77 U. CIN. L. REV. 405 (2009) (tracing the characteristics of many failed CEOs, including Ken Lay, Bernie Ebbers, and Conrad Black). These characteristics, of course, are not limited to felonious CEOs. They may also characterize legendarily successful CEOs. See id. (describing Jack Welch).

108. Id. at $420-21$. 
becomes uncontrollable. Sometimes, they claim, they are merely trying to meet the company's earnings estimates, which they think of as a harmless and temporary exercise. ${ }^{109}$ Often they are engaged in some form of rescue fantasy and believe, in the face of contrary evidence, that they can somehow "with just a little more time" make things right. ${ }^{110}$ Sometimes, they are working to protect their own equity stakes and-driven to stay at the top of the pay scale pyramid - become blinded to their crimes. Are these CFOs fantasists? Simply optimists? Have they always been rule breakers or do circumstances and stress reset their ethical thermostats? Do their employment histories or details in their employment files tell us anything we ought to know?

The SEC should also learn more about the middle management defendants who get swept up in the others' misconduct, and, for reasons of loyalty, fear, or some perverted sense of adventure, become active participants in organizational fraud. Administrative assistants, bookkeepers, tax accountants, and even in-house counsel have ended up in prison for joining a criminal team. What do these people have in common? Are they meek and servile and unable to resist recruitment? Or are they ambitious and outgoing, and think of themselves as born leaders? Do they pride themselves on being problem solvers? Are they acting simply out of economic need?

\section{Gathering Information About Other Securities Fraud Offenders}

There are other categories of offenders, as well. Brokers who steal from their customers, ${ }^{111}$ brokers who defraud their customers by misrepresenting the risks of the products they are selling; ${ }^{112}$ pump-and-dump artists who find their victims on the Internet; ${ }^{113}$ and insider traders who are confident that their

109. See Alexei Barrionuevo, Enron Figures Tell How Results Were Manipulated, N.Y. TIMES, Feb. 28, 2006, at C3 (describing the testimony of Wesley H. Colwell, Enron's Chief Accounting Officer, that he sometimes "dipped into reserve accounts" in order to "beat analysts' estimates").

110. See Former CEO Indicted in WorldCom Scandal, Seattle Times, Mar. 3, 2004, at E1 (recounting the story of Scott Sullivan, WorldCom's CFO: "[I manipulated financial statements] in a misguided effort to preserve the company to allow it to withstand what I believed were temporary financial difficulties.").

111. See SEC v. Zandford, 535 U.S. 813 (2002) (tracing story of broker who stole from his disabled clients).

112. See Bloomberg News, Former Broker at Credit Suisse Found Guilty, N.Y.TIMEs, Aug. 18, 2009, at B2 (describing defendant's sales of products he falsely described as "backed by federally-guaranteed student loans and a safe alternative to bank deposits. The products were actually linked to auction-rate securities.").

113. See SEC v. C. Jones \& Co., SEC Litigation Release 20940 (Mar. 10, 2009) (noting that defendant posted "baseless projections and other financial information" without disclosing he was being compensated 
trades can never be traced. ${ }^{114}$ Are these people bullies? Micromanagers? Are they conspicuously religious? Openly hedonistic? Do they need uppers (or downers) to get through the day?

By employing behavioral experts who could systematically study the personality traits and behavioral characteristics of these securities law violators, the Enforcement Division could more effectively target the firms and individuals who deserve investigation, especially in the face of tens of thousands of tips every year. ${ }^{115}$ Applying the insights of the behavioral unit, the Enforcement Division could deploy its investigational resources toward the types of people who are likely to generate the most harm.

The point of the behavioral unit, by the way, is not to develop the kind of "profile" by which behavioral generalizations would frame SEC investigations. I certainly do not have in mind the SEC saying "round up all the bald-headed 40-year-old former used-car salesmen who currently smoke cigars, engage in the sale of penny stocks, and also have a drinking problem." Rather, the point is to identify commonalities among defendants-if such exist - and to use that knowledge strategically on a case-by-case basis. Decisions about sanctions based on real data and not merely on gut feelings can only enhance the task of securities law enforcement. We are not talking about fleets of people here. With hundreds of cases each year in the Enforcement Division, ${ }^{116}$ a team of fewer than a dozen people-forensic psychologists and criminologists, together with support personnel-could probably handle the work.

The obvious objections to this proposal are the cost and institutional disruption involved in creating a new operating unit; the inevitable clash of wills between lawyers and non-lawyers in what has traditionally been a lawyer-centric agency; the inadequacy of the available population of offenders to give rise to any meaningful statistical data (defendants who have gone through the SEC enforcement system number in the thousands rather than the tens of thousands - or more - offenders typically involved in predictive datagathering); the likelihood that retrospective reviews of information about defendants will prove unfruitful because nobody asked the defendants (or others with knowledge) the right questions; notwithstanding these criticisms,

by the company and was, at the time of the posting, selling the company's stock).

114. See SEC v. Accord, SEC Litigation Release 21132 (July 15, 2009) (describing insider trading violations by a lawyer and an accountant, as well as in-laws and friends, who acquired shares of a company shortly before it issued an announcement that it was to be acquired).

115. See supra note 32 and accompanying text.

116. See infra note 158 and accompanying text. 
the likelihood of excessive reliance on actuarial, rather than clinical, assessments of targets of investigations and defendants; ${ }^{117}$ and the notion that behavioral tracking, as opposed to fugitive tracking or asset tracking, is a law enforcement luxury. ${ }^{118}$

One might respond to these objections by organizing the behavioral unit as a pilot project, and authorizing it subject to a sunset provision to test whether the unit has been effective in assisting existing Enforcement Division personnel. A better response is to imagine that the addition of behavioral experts to the lawyer-investigator teams that now define and pursue securities fraud wrongdoers might just enrich the agency's performance. Just as anthropologists have brought a new skill set into the corporate world, ${ }^{119}$ and other social scientists have influenced military strategies, ${ }^{120}$ behavioral scientists could bring new perspectives to the prioritization and practice of securities law enforcement.

\section{THE ENFORCEMENT DiVISION SHOULD IDENTIFY LIKELY RECIDIVISTS AT the EARliest Possible Stage and Create a Monitoring Program for \\ SeCurities LAW Violators Who Present a ReCidivism Profile}

Whether or not the Enforcement Division systematically assesses all the defendants with whom it deals, it should develop a sense of what drives and distinguishes a securities fraud recidivist. Recidivism may have many sources: simple greed; technocratic competence unencumbered by a sense of right and wrong; uncontrollable compulsion; outright criminality with a desire to do harm; and some combination of one or more of these traits. ${ }^{121}$

117. When the sample size is sufficient, "preponderant evidence shows that statistical techniques of risk assessment are clearly superior to clinical assessments." BRIAN J. OSTROM ET AL., OFFENDER RISK Assessment in Virginia: A Three Stage Evaluation 28 (2002), http://www.vcsc.state.va.us/ risk_off_rpt.pdf (“[S]tudies show that statistical methods outperform both mental health professionals and correctional caseworkers in predicting recidivism.").

118. Skeptics might also suggest that behavioral profiling, however scientifically-based, is just a modern version of the practice of phrenology.

119. See Posting of Tom Davenport to Harvard Business Review Blog, The Rise of Corporate Anthropology, http://blogs.harvardbusiness.org/davenport/2007/11/the_rise_of_corporate_anthropo.html (Nov. 28, 2007, 9:01 EST). Corporate anthropologists use their observational and interviewing skills to study consumer behavior and workflow issues, examine corporate cultures, and help build communities within organizations. Id.

120. Vanessa M. Gezari, RoughTerrain, WASH. Post, Aug. 30, 2009, (Magazine), at W16 (describing the use of embedded anthropologists and psychologists who are assisting front-line soldiers in Afghanistan).

121. See generally Neal Shover \& Andy Hochstetler, Choosing White-Collar Crime (2006). Julian Roberts has recognized "there may be many reasons for [recidivism], including defiance, weak will, force of circumstances, or even physiological causes (the offender may have an addiction that is responsible 
Recidivism surfaces regularly at the SEC. ${ }^{122}$ Many offenders, particularly Ponzi scheme offenders, have long track records of similar fraud schemes. ${ }^{123}$ They often also have related histories of misappropriation, fraud, or professional misconduct. ${ }^{124}$ The Enforcement Division does not seem to know what to do with these people. So, time after time, we see defendants cycling and recycling through the SEC civil enforcement system. Some defendants have been enjoined by the SEC three, four, five, or even six times. ${ }^{125}$

\section{A. Conducting a Risk Assessment}

It is fair to ask how the SEC is supposed to know when it's got a likely recidivist on its hands. When there is a history of documented and similar misconduct in the defendant's record, it's easy. ${ }^{126}$ When a defendant appears as a first offender, however, it can be much more difficult. Predictions are inevitably imperfect. Still, there are some markers of likely recidivism, even for first offenders, and the Enforcement Division should become more familiar with those markers.

I have argued elsewhere, for example, that many con artists and Ponzi schemers suffer from Antisocial Personality Disorder (APD), the technical term for what is often referred to as "psychopathy." This condition is characterized by lifelong habits of lying, conning, cheating, and stealing. Most experts agree the condition is untreatable and that persons who suffer from

\footnotetext{
for his offending) ....”). Julian V. Roberts, Punishing PeRsistent OfFEnders: EXPloring COMMUNITY AND OfFEnder Perspectives 62 (2008) [hereinafter RoBerts, PUnishing PERsistent OfFENDERs].

Youngjae Lee has offered a similar catalog of traits that may account for recidivism: [The possibilities include] cruelty, malice, abusiveness, arrogance (manifesting in the belief that rules of the society do not apply to them, callousness, dishonesty (if the crimes involve fraud), greed, hatred (if the crimes are motivated by hateful feelings), indifference (to human suffering), lack of discipline (if the crimes result from an inability to stick to a law-abiding path), weakness of will (if the crimes results from an inability to resist temptations), insensitivity, irresponsibility, or ruthlessness. Youngjae Lee, Recidivism as Omission: A Relational Account, 87 TEX. L. REV. 571, 586 (2009).

122. See generally Jayne W. Barnard, Securities Fraud, Recidivism and Deterrence, 113 PENN. ST. L. REV. 189 (2008) [hereinafter Barnard, Securities Fraud, Recidivism, Deterrence] (examining the careers of several recidivist securities fraud offenders).

123. See id.

124. See supra note 101 and accompanying text.

125. Barnard, Securities Fraud, Recidivism, Deterrence, supra note 122 (setting out numerous examples of multiple sequential injunctions).

126. In a study of offenders prosecuted criminally, "serial offenders [were] more than $500 \%$ more likely to recidivate ... than non-serial offenders [were]." Larry Laudan, Taking the Ratio of Differences Seriously: The Multiple Offender and the Standard of Proof, or, Different Strokes for Serial Folks 5 (July 8 , 2009), available at $\mathrm{http} / / / \mathrm{ssrn} . \mathrm{com} / \mathrm{abstract}=1431616$.
} 
APD are unlikely —indeed, unable — to reform. ${ }^{127}$ These people are devoid of conscience and incapable of remorse even when they have grievously damaged others. They do not respond to imprisonment or threats of imprisonment, let alone something as diaphanous as an obey-the-law injunction or a cease-anddesist order. ${ }^{128}$ Financial penalties also do not deter them.

It is often difficult to imagine these people as true predators. They are typically smart, charming, raffish, witty, and glib. ${ }^{129}$ Little wonder, then, that victims find these schemers and their stories so appealing. It is harder to understand why the Enforcement Division seems to fall into the same trap.

My theory is that most of the recidivists who come before the SEC - perhaps all of them - could have been identified as likely recidivists early or earlier in their careers. Even when they are before the SEC for the first time, these defendants could be identified as likely recidivists if the Enforcement Division had a behavioral unit (or trained individuals) with an understanding of personality disorders.

My prescription here is that the Enforcement Division should recognize the existence of APD and consider the likelihood that many individuals who come before it suffer from this chronic disorder. ${ }^{130}$ The Division should treat defendants with a pattern of lying and scamming as special targets. It should (1) work to identify at an early stage those defendants who, based on their business and social history, appear constitutionally unable to confine their behavior to social or legal norms; (2) divert those defendants to investigators and attorneys with behavioral expertise (a Recidivism Task Force); ${ }^{131}$ (3) refer many of these defendants for criminal prosecution rather than relying on civil enforcement; (4) refer any of these defendants who have previously been sanctioned by the SEC, for criminal prosecution; ${ }^{132}$ (5) within the civil enforcement context, use its knowledge of defendants' behavioral profiles to build the case for injunctive relief and occupational bars; and (6) design very

127. Barnard, Securities Fraud, Recidivism, Deterrence, supra note 122.

128. $I d$.

129. See John Seabrook, Suffering Souls: The search for the roots of psychopathy, NEW YORKER, Nov. 10, 2008, at 64, 67 (describing psychopaths as "charming and intelligent." The "psychopath talks 'entertainingly,' [psychiatrist Hervey] Cleckley explain[s], and is 'brilliant and charming,' but nonetheless 'carries disaster lightly in each hand.'”).

130. Three percent of the U.S. male population is said to suffer from some form of APD. Surely, the percentage of SEC defendants who have a history of scamming and conning is significantly higher than that.

131. See Barnard, Securities Fraud, Recidivism, Deterrence, supra note 122, at 224 (recommending the creation of a Securities Fraud Recidivism Task Force within the Enforcement Division).

132. This "no second chance" rule is further discussed in Part VI, infra. 
specific remedial provisions to minimize the likelihood of recidivism and maximize the chance that defendants who do recidivate are quickly detected.

Targeting likely recidivists for special treatment and heightened scrutiny is, of course, not a new idea. The federal Sentencing Guidelines already recognize that a defendant with a criminal history is deserving of harsher treatment than a first-time offender. ${ }^{133}$ And almost every punishment theory shares the view that prior offenses are relevant to decisions about current punishment. ${ }^{134}$ The same should hold true in civil enforcement proceedings.

\section{B. Post-Sanction Monitoring}

The SEC should do more than just catalog personality traits and diagnose defendants' personality disorders in order to identify likely recidivists. It should use what it knows. Importantly, it should do more than treat likely recidivists as if they intend to reform and become good citizens and then (as often currently occurs) send them on their way with an obey-the-law injunction. ${ }^{135}$ The vast majority of the SEC's civil enforcement actions result in settlement. Thus, in any case in which an individual defendant presents a recidivism profile and is not referred for criminal prosecution, the Enforcement Division should insist as a condition of settlement on consent to post-sanction monitoring. This monitoring might include unscheduled office and home visits; access to phone records, bank records and state and federal income tax returns; employment verification; periodic interviews with family members, neighbors and co-workers; physical surveillance and computer surveillance; and submission of periodic self-reports by the defendant. The decision to accept such monitoring would be voluntary in the sense that a defendant wishing to avoid it would be welcome to go to trial and convince the judge that he or she is innocent or undeserving of a monitoring regime. Alternatively, the defendant may want to negotiate the specifics of the monitoring provision-lawyers negotiate the fine points of SEC settlements every day. ${ }^{136}$

The obvious objections to this proposal are the cost of monitoring; the risk of over- or under-inclusiveness (false positives and false negatives) in

133. See 2008 Federal Sentencing Guidelines Manual Chapter 4, http://www.ussc.gov/ 2008guid/GL2008.pdf ("Criminal History and Criminal Livelihood").

134. See Roberts, Punishing Persistent Offenders, supra note 121, at 90-92 (summarizing seventeen theories of sentencing and the role that recidivist sentencing premiums or first-offender discounts plays in each).

135. See supra note 122 and accompanying text.

136. See Barnard, Corporate Therapeutics, supra note 89 , at $816-20$ (describing some of the dynamics of settlements with the SEC). 
identifying those defendants who should be subject to a monitoring regime; privacy issues; the risk of "branding" a first-offender as a recidivism risk, thus enhancing the likelihood of recidivism rather than reducing it; usurpation of authority from the criminal justice system (SEC monitoring would, after all, replicate much of what the FBI is supposed to do); and a general sense that government monitoring, even of people who have defrauded their neighbors, is somehow un-American. One shouldn't have to forfeit his privacy rights in the absence of a criminal prosecution.

A monitoring regime, however, offers several advantages over the current practice of privileging hope (in the form of an obey-the-law injunction) over experience (the many cases in which fraud defendants recidivate): Awareness of the SEC's ongoing interest in one's activities is surely a more effective deterrent than believing (probably correctly) that the SEC has moved on to other matters; regular monitoring offers the possibility of early or earlier intervention in the form of an asset freeze or contempt of court proceeding, in the event the defendant recidivates; monitoring accompanied by quick action is likely to be less costly than having to initiate an entirely new enforcement proceeding "from scratch." It is certainly more attractive to defendants (and less costly to the public) than the alternative of a criminal prosecution.

\section{The SEC Should ARTiCulate a SANCTION Policy FOR INDIVIDUAL DefEndants That Is Proportionate, Progressive, Remedial, AND REAL}

Let us assume that the monitoring proposal is not adopted - too expensive, too exotic, perhaps unconstitutional. The SEC Enforcement Division nevertheless should take steps to articulate a coherent sanction policy for securities law violators rather than continuing to employ the current "grab bag" approach to imposing civil remedies.

Over the years, the SEC has successfully importuned Congress to provide it with a rich assortment of remedial enforcement tools - disgorgement orders, cease-and-desist orders, injunctions, civil penalties, penny stock bars, and occupational bars. The SEC also has statutory authority to seek "any equitable relief that may be appropriate or necessary for the benefit of investors." "137 There is little, in short, that the SEC cannot seek as a remedy for securities law violations. The obvious limit is imprisonment —only the Department of Justice can seek that punishment. 
Some observers have argued that the SEC, too, should be able to seek criminal penalties, ${ }^{138}$ but that is not the point that I want to make here. Rather, recognizing that the SEC is a civil regulatory agency, and accepting that, as such, it should be confined to seeking civil remedies, I submit that the SEC can and should be more rational in its deployment of remedial tools. Specifically, it should articulate, and then adhere to, a sanction policy that (1) aligns sanctions with culpability and harm; (2) escalates sanctions for repeat offenders; (3) minimizes, through intelligent remedial techniques, the likelihood of repeated misconduct; and (4) doesn't waste the agency's time on pointless or cosmetic sanctions.

How might such a sanction policy work? Some securities law violators, it is fair to say, are "situational" wrongdoers - decent, "conventional people" who get caught up in criminal situations. ${ }^{139}$ Others are simply bad people who would, in a different environment or with different educational credentials, be just as likely to use a gun and burglarize your home. SEC sanctioning policy should treat these offenders differently.

Thinking about these two models of offenders, we recognize that these descriptions are consistent with two general theories of human behavior-the "dispositionist" theory and the "situationist" theory. ${ }^{140}$ A dispositionist believes, for example, that Jones has filed for bankruptcy because he is lazy and lacks self-discipline. A situationist believes that Jones has filed for bankruptcy because, after a medical crisis in his family and, no matter how hard he worked, he couldn't keep up with the family's bills.

Most modern observers agree that neither the dispositionist theory nor the situationist theory adequately captures the process by which most people take action or make decisions about how to behave. A middle ground, known as the "interactionist" theory, better captures the way most people operate. Decisions

138. See Zachary A. Goldfarb, The SEC's New Enforcer: Former U.S. Prosecutor Charged With Adding Muscle, Restoring Agency's Image, WASH. Post, Apr. 7, 2009, at A16 (noting that, in a recent speech SEC Commissioner Luis Aguilar had said "the agency needs Congress to give it new legal powers. 'The commission needs authority to bring criminal charges where the Department of Justice has declined to do so,' he said.").

139. David Weisburd, Elin Waring \& Nicole Leeper Piquero, Getting Beyond the Moral Drama of Crime: What We Learn From Studying White-Collar Criminal Careers, in CORPORATE AND WHITE-COLLAR CRIME (John Minkes \& Leonard Minkes eds., 2008).

140. See generally Adam Benforado \& Jon Hansen, The Great Attributional Divide: How Legal Policy Debates Are Shaped by Divergent Views of Human Nature, 57 EMORY L.J. 311 (2008) (describing generally the "situationist" and "dispositionist" views of human behavior). 
about behavior (including unconscious decisions) are generally a product of the interaction between disposition and situation. ${ }^{141}$

Criminologists use a more specific approach to white-collar crime, noting that financial wrongdoers typically exist on a continuum running from "crisis responders" to "opportunity takers" to "opportunity seekers" to "chronic offenders." ${ }^{142}$ Crisis responders are the least culpable for their crimes; chronic offenders deserve (and generally receive) far greater punishment.

By introducing the psychologists to the criminologists and putting their concepts together, we can imagine a fraud culpability continuum that looks something like this:

\begin{tabular}{|l|l|l|l|}
\hline Situationist & \multicolumn{2}{|l|}{ Dispositionist } \\
\hline \multicolumn{3}{|c|}{ Interactionist } \\
\hline Crisis Responder & Opportunity Taker & Opportunity Seeker & Chronic Offender \\
\hline
\end{tabular}

Now, let us assume we have a group of securities law violators, all of whom have acted with the requisite scienter and all of whom have caused demonstrable harm. A rational sanctioning policy would reflect the notion that the "dessert" of their wrongdoing should be tied, at least in part, to the defendants' position on the culpability continuum.

How might this work? First, the Enforcement Division (preferably, with the help of its behavioral unit) ${ }^{143}$ would situate these defendants somewhere along the continuum. Those who reside at the "chronic offender" end of the scale would be referred to the Justice Department for criminal prosecution. ${ }^{144}$ There is no point in trying to sanction these offenders with civil sanctions. And, to be clear, where there is clear and convincing evidence that the offender is a "chronic offender" on the basis of prior interactions with the SEC

141. See Edward J. Imwinkelreid, Reshaping the "Grotesque" Doctrine of Character Evidence: The Reform Implications of the Most Recent Psychological Research, 36 Sw. U. L. REV. 741, 753-54 (2008).

142. WEISBURD, WARING \& CHAYET, supra note 104. A "crisis responder" is someone who responds to a personal or professional crisis by resorting to crime. Id. at 59. An "opportunity taker" commits a crime because a sudden or unusual opportunity arises that is too good to pass up. Id. at 64. An "opportunity seeker" spends considerable time imagining and engineering a role in fraudulent schemes. Id. at 78. A "chronic offender" is a person who has a demonstrated record of recidivism. See id. at 53, 74.

143. See supra Part IV.

144. Of course, other violators may also be referred for criminal prosecution, even though there is no evidence that they are or are likely to be chronic offenders. For example, high-profile mega-violators like Jeffrey Skilling and Bernie Ebbers were appropriately diverted to the criminal justice system. Ditto the colleagues who aided and abetted them. 
or other law enforcement agencies, there should be no second chance for civil enforcement. Chronic offenders should be criminally prosecuted. The SEC should end the practice of seeking sequential injunctions for members of this group. ${ }^{145}$

Offenders at the "crisis responder" end of the scale, on the other hand, should generally be subject only to disgorgement of profits and (perhaps) to entry of a cease-and-desist order. They may also be candidates for a civil penalty. ${ }^{146}$ They will only rarely be suitable candidates for imposition of an injunction or any kind of occupational bar. ${ }^{147}$ Monitoring is unnecessary for this population. Crisis responders, in short, are not scoundrels and pose little threat to the investment markets. Heaping unnecessary sanctions on these offenders - assuming they are correctly categorized - is a waste of law enforcement resources and undermines respect for the SEC.

The most interesting defendants, of course, are the ones in the middle of the spectrum between the chronic offenders and the crisis responders. The opportunity takers present, for me, the most interesting challenge. Opportunity takers do not set out to engage in fraud, but are willing to do so if the circumstances seem sufficiently inviting. Their level of scienter is, by definition, higher than that of a crisis responder but lower than that of an opportunity seeker. And, unlike opportunity seekers, the risk of recidivism for an opportunity taker is low. Thus, opportunity takers should rarely be

145. There will, of course, be exceptions to the "no second chance" rule, where the evidence may not support a criminal conviction but can support a civil judgment. But those exceptions should be rare. Chronic offenders are dangerous predators and should be dealt with in the criminal justice system. The preference of some U.S. attorneys to reject these cases as "too small to prosecute" is bad public policy and should be addressed at a higher level within the Justice Department.

146. First-tier penalties are available for defendants who violate any provision of the federal securities laws. 15 U.S.C. $\S 78 \mathrm{u}$ (d)(3)(B)(i) (2006). The maximum first-tier penalty for a natural person is the greater of $\$ 5,000$ or the amount of his pecuniary gain from the violation. Second-tier penalties are available for defendants who violate any provision of the federal securities laws in a manner that involved fraud, deceit, manipulation, or deliberate or reckless disregard of a regulatory requirement. 15 U.S.C. $§ 78 \mathrm{u}(\mathrm{d}$ )(3)(B)(ii) (2006). The maximum second-tier penalty for a natural person is the greater of $\$ 50,000$ or the amount of his pecuniary gain from the fraud.

Third-tier civil penalties are available for the same defendants as those who are eligible for a secondtier penalty, but third-tier penalties are imposed in cases of frauds that "directly or indirectly result ... in substantial losses or create a significant risk of substantial losses to other persons." 15 U.S.C. $\S 78 \mathrm{u}(\mathrm{d})(3)(\mathrm{B})(\mathrm{iii})$ (2006). The maximum third-tier penalty for a natural person is the greater of $\$ 100,000$ or the amount of his pecuniary gain from the fraud.

147. See Jayne W. Barnard, Rule 10b-5 and the "Unfitness" Question, 47 ARIz. L. REV. 9 , 54 (2005) (arguing that situational offenders should rarely be subject to an officer-or-director bar). 
candidates for an injunction or an occupational bar. They may be candidates for a civil penalty. ${ }^{148}$ Monitoring should be a low priority for this population.

Opportunity seekers ratchet up the sanctioning stakes. In the jargon of the entrapment defense, opportunity seekers are people with a predisposition to crime. ${ }^{149}$ They are natural candidates for imposition of injunctions and, often, for occupational bars. They may also be candidates for a civil penalty. ${ }^{150}$ This is a population for whom monitoring may be appropriate.

Categorizing offenders systematically more or less along these lines will lead to more coherent, proportional sanctions for securities law violators. It will also permit an escalation of sanctions for those who present a risk of future harm. It will put monitoring resources where they are most needed. And, finally, it will ensure that the truly predatory securities law violators - the chronic offenders - are sanctioned appropriately by the criminal justice system, not treated ineffectively with civil sanctions that they can (and often do) ignore.

There is one last factor in any rational sanctioning policy. Where defendants have been diverted for criminal prosecution and have pleaded or been found guilty, the SEC should generally leave them alone. Often, the Enforcement Division lags behind the Justice Department and, after a defendant has gone off to prison, pursues some unnecessary sanction like an officer-and-director bar, ${ }^{151}$ an occupational bar,${ }^{152}$ or an injunction. ${ }^{153}$ This kind of piling on is wasteful and unwise. ${ }^{154}$ If, as Robert Khuzami has said, the goal of Enforcement is to use its resources "strategically" and achieve meaningful results, ${ }^{155}$ then pursuing civil sanctions against a defendant who is languishing in prison makes little sense. ${ }^{156}$ And keeping cases open rather than quickly

148. See supra note 146 .

149. See Paul Marcus, The Entrapment Defense $\S 2.03 B$ (2009).

150. See supra note 146.

151. See, e.g., SEC v. Bennett, SEC Litigation Release No. 20660 (July 30, 2008) (barring Phillip Bennett-now in jail for sixteen years - from serving in the future as an officer or director of a public company).

152. See, e.g., In re Madoff, Exchange Act Release No. 60118 (June 16, 2009) (barring Bernie Madoff-now in jail for 150 years-from serving as an investment adviser).

153. See, e.g., SEC v. Bennett, supra note 151 (enjoining Phillip Bennett from future violations of the federal securities laws).

154. See Thomas Gorman, Restoring SEC Enforcement: Prosecutorial Discretion and Coordination, SEC Actions, Apr. 20, 2009, http://www.secactions.com/?p=1029 (citing examples of where "there was no apparent need for the SEC to step in and investigate" and noting that "there are instances when it may be more prudent for the Commission to step back and conserve its resources, letting another agency take the lead.").

155. See Khuzami, My First Hundred Days, supra note 25.

156. And, if there $i s$ value in pursuing such sanctions, then Congress could easily provide that anyone 
dismissing them when the defendant has become incapacitated is a very poor use of the Division's legal talents. ${ }^{157}$

\section{THE SEC SHOULD GATHER AND DisSEMINATE HONEST INFORMATION ABOUT THE IMPACT OF FRAUD IN THE SECURITIES MARKETS}

The SEC currently dispenses information in an annual report, which is (as are most annual reports) self-serving and designed to obfuscate ugly truths. For example, in its nicely-titled Performance and Accountability Report for fiscal year 2008, we can see that, during that period, the SEC Enforcement Division initiated 671 enforcement actions - "the second highest number of enforcement actions in agency history" 158 — and "successfully resolved $92 \%$ of its cases." $" 159$

This report does not tell us how much money was lost to Ponzi schemers in Fiscal Year 2008; how many SEC investigations ended up without further action because the defendant lives outside of the U.S. and cannot be located or served with process; where, geographically, the Ponzi schemers and their victims are located; the age and demographic characteristics of the victims; how many Enforcement cases involved documented recidivists; how many SEC investigations ended up in criminal referrals to the Justice Department; how many of those referrals hit a brick wall and were rejected for lack of evidence or lack of resources; how many criminal actions were successful and how much money was recovered in the form of restitution. The public is not told how much money was lost to Internet scams or to thieving brokers.

Professor Don Langevoort has suggested that the SEC, like the brokerage industry, has a very good reason for not wanting to broadcast the scope of fraud in the securities markets. ${ }^{160}$ The SEC wants the public to believe the SEC is protecting them and that the securities markets offer a reasonably level

\footnotetext{
who is imprisoned for securities fraud is automatically enjoined and/or barred. There are many models for such a statutory provision. See Jayne W. Barnard, The SEC's Suspension and Bar Powers in Perspective, 76 TUL. L. REV. 1253, 1269 n.84 (2002) (describing automatic bar statutes triggered by a criminal conviction).

157. See, e.g., SEC v. Dreier, SEC Litigation Release No. 20823 (Dec. 8, 2008) (announcing the filing of a civil action against lawyer accused of selling $\$ 113$ million in bogus promissory notes). Dreier is now serving a twenty-year prison term. The SEC civil case is still pending.

158. SeC AnN. Performance \& ACCOUntability ReP., 2008, http://www.sec.gov/about/ secpar/secpar2008.pdf\#sec2, at 27.

159. Id.

160. Donald C. Langevoort, Managing the "Expectations Gap" in Investor Protection: The SEC and the Post-Enron Reform Agenda, 48 VILL. L. ReV. 1139, 1165 (2003).
} 
playing field. The fact is, however, that the market is rife with fraud and abuse. Just since January 2009, the Enforcement Division has filed more than forty cases involving Ponzi schemes or Ponzi-like payments. ${ }^{161}$ Shouldn't the public demand some kind of "Ponzi Watch" website with information about these calamities? The public should know more about the kinds of "products" these Ponzi schemers are selling. The SEC should maintain a registry of Ponzi schemers as well as a running tab of Ponzi scheme losses. ${ }^{162}$

I might also make the case for an informed, aggressive media education campaign, much like that now utilized by the military services and some law enforcement agencies. It is now routine for journalists to be present in war zones or participate in ride-alongs with local police officers. Some law enforcement agencies have even opened themselves up to reality TV. ${ }^{163}$ Why not offer some version of that kind of media access at the SEC Enforcement Division? Why not encourage one of the crime-reenactment shows to reconstruct one of the most despicable affinity fraud schemes? ${ }^{164}$

In fact, I will hold that thought for another occasion. For now, let me merely urge that the SEC provide much more candid and useful information about the nature and magnitude of the wrongdoing with which it deals every day. There is little value and much mischief in continuing to play hide-the-ball.

\section{CONCLUSION}

Let us conclude where we began - with the tumultuous year that gave rise to the election of a new President, the appointment a new SEC Chairman, a top-to-bottom shake-up of the Enforcement Division, and the discovery of some of the biggest and cruelest frauds in American history.

The Enforcement Division has made admirable progress this year in confronting the need to update its priorities and enhance its workforce. The recommendations in this Article would further build on the progress the Division's new leaders have made to date.

The challenge, of course, will be to keep the Division "nimble," and to maintain Enforcement's energy level well into the future. Whatever else

161. Khuzami, My First Hundred Days, supra note 25.

162. See Barnard, Securities Fraud, Recidivism, Deterrence, supra note 122, at 225 (advocating for the creation of an online registry of Ponzi schemers, modeled on similar registries for sex offenders and physicians who have been disciplined for misconduct).

163. See Wikipedia, COPS (TV series), http://en.wikipedia.org/wiki/COPS_(TV_series).

164. See, e.g., SEC v. Tri-Energy, Inc., SEC Litigation Release No. 21000 (Apr. 15, 2009) (describing a Ponzi scheme that raised $\$ 50$ million through solicitations aimed at people who thought they were contributing to humanitarian causes). 
Congress has to say about the SEC's future, the front-line soldiers in the SEC's Enforcement Division are our last best hope to ensure the protection of investors. 